Jurnal Konstruksi Hukum | ISSN: XXXX | E-ISSN: XXXX

Vol. 1, No. 2, Oktober 2020, Hal. 260-265| Available Online at https://www.ejournal.warmadewa.ac.id/index.php/jukonhum

DOI: https://doi.org/10.22225/jkh.1.2.2592.260-265

\title{
UPAYA PERLAWANAN SEBAGAI AKIBAT PERNYATAAN DISMISSAL OLEH KETUA PENGADILAN TATA USAHA NEGARA (Studi Kasus di Pengadilan Tata Usaha Negara Denpasar)
}

\author{
Anak Agung Tias Sandya Dianti, Anak Agung Laksmi Dewi, I Nyoman Sugiarta \\ Fakultas Hukum Universitas Warmadewa, Denpasar-Bali, Indonesia
}

\begin{abstract}
Abstrak
Pengadilan Tata usaha Negara (PTUN) diadakan untuk mengatasi pembenturan kepentingan yang menyebabkan perselisihan antara badan atau Pejabat Tata Usaha Negara dengan warga masyarakat. Objek sengketa yang menjadi wewenang PTUN adalah suat penetapan tertulis yang dikeluarkan oleh Badan atau Pejabat Tata Usaha Negara yang menimbulkan akibat hukum dan merugikan bagi seseorang atau badan hukum secara perdata yang termasuk dalam pengertian keputusan Tata Usaha Negara dan termuat dalam Pasal 2 Undang-Undang No 5 Tahun 1986. Kajian ini menyoroti penyelesaian upaya perlawanan sebagai akibat pernyataan dismissal oleh Ketua Pengadilan Tata Usaha Negara dan dasar pertimbangan Majelis Hakim dalam memutus kasus tersebut. Untuk mencapai tujuan ini, explorasi dengan penelitian ini dilakukan menggunakan desain penelitian kualitatif. Hasil menunjukkan bahwa Undang-Undang PTUN yang digunakan sebagai acuan dalam menyatakan gugatan dapat diproses atau tidak melalui tahap penyaringan, yang kemudian akan diperiksa dan diputus oleh Hakim yang sesuai, ditunjuk oleh Ketua Pengadilan dengan acara singkat. Apabila perlawanan pengugat diterima, penetapan dismissal tidak lolos oleh ketua pengadilan dibatalkan. Selanjutnya pokok gugatan akan diperiksa dan diputus menurut acara biasa, dan sebaliknya, apabila verzet ditolak oleh Majelis Hakim yang memeriksanya, maka tidak ada lagi upaya hukum yang dapat ditempuh oleh penggugat. Dalam memutus perkara tindakan perlawanan sebagai akibat dismissal, dinyatakan bahwa keputusan objek sengketa tersebut termasuk dalam kategori keputusan yang dikecualikan sebagai Keputusan Tata Usaha Negara.
\end{abstract}

Kata Kunci: Pengadilan Tata Usaha Negara; Dismissal Proses; Upaya Perlawanan

\begin{abstract}
The State Administrative Court (PTUN) is held to resolve conflicts of interest that cause disputes between State Administrative Bodies or Officials and citizens. The object of the dispute becoming the authority of PTUN is a written stipulation issued by a State Administration Agency or Official which causes legal consequences and harm to a person or legal entity in a civil manner which is included in the definition of a State Administrative Decree and contained in Article 2 of Law No.5 1986. This study focuses on the resolution of resistance efforts as a result of dismissal statements by the Chairman of the State Administrative Court and the basis for consideration of the Panel of Judges in deciding the case. To achieve this goal, exploration with this research is carried out using a qualitative research design. The results show that the PTUN Law which is used as a reference in stating a lawsuit can be processed or not through the screening stage, which will then be examined and decided by the appropriate Judge, appointed by the Chief Justice with a short procedure. If the plaintiff's resistance is accepted, the dismissal determination does not pass by the head of the court is canceled. Furthermore, the subject of the lawsuit will be examined and decided according to an ordinary procedure, and vice versa, if the verzet is rejected by the panel of judges examining it, the plaintiff can no longer take legal action. In deciding cases of resistance action as a result of dismissal, it is stated that the decision on the object of the dispute is included in the category of decisions that are exempt from being a State Administrative Decree.
\end{abstract}

Keywords: State Administrative Court; Dismissal Process; Resistance 


\section{PENDAHULUAN}

Rapat Permusyawaratan, atau tahap penyaringan diatur dalam Pasal 62 UU Pengadilan Tata usaha Negara (PTUN) yang merupakan tahap pemeriksaan sebelum pemeriksaan pokok perkara. Ketua Pengadilan memeriksa gugatan yang masuk, yang kemudian akan diteliti apakah gugatan tersebut telah memenuhi syarat-syarat sebagaimana diatur dalam UU No 5 Tahun 1986 (Soetami, 2005). Ketua pengadilan dapat menyatakan gugatan masuk dalam klasifikasi atau tidak yang dituangkan dalam suatu penetapan, yang berisi alasan-alasan mengapa gugatan yang tersebut tidak memenuhi syarat atau telah memenuhi persyaratan melalui proses dismissal (Elijana Dkk., 2015). Ketua PTUN mempunyai hak dalam menilai gugatan tersebut untuk dinyatakan tidak diterima, sehingga pihak penggugat diberikan opsi atau pilihan untuk dapat mengajukan upaya hukum perlawanan sebagaimana ketentuan dalam UU PTUN. Pengajuan upaya perlawanan yang dilakukan penggugat atas pernyataan itu akan diperiksa dan diputus dengan acara singkat.

Cara pemeriksaan dengan acara singkat digunakan dalam menyelesaikan suatu upaya perlawanan dengan harapan agar mampu mengikis rintangan-rintangan yang mungkin terjadi dalam penyelesaian perkara secara cepat mengenai sengketa yang diajukan (Hasanah, 2016). Selain itu cara yang sederhana dan singkat ini dapat menjadi kontrol arus masuknya perkara yang sebenarnya tidak memenuhi syarat untuk diproses di PTUN yang dilakukan dalam proses pemeriksaan gugatan perlawanan oleh Hakim dalam upaya perlawanan hanya menguji tepat tidaknya penggunaan Pasal 62 huruf A sampai dengan huruf e UU PTUN oleh Ketua PTUN di dalam mengeluarkan penetapan dismissal (Pradana \& Marwanto, 2013; Zurahmah \& Umar, 2014; Pattipawae, 2015).

Guna memperjelas bagaimana dasar pertimbangan Majelis Hakim dalam memutus upaya perlawanan sebagai akibat dari pernyataan dismissal oleh Ketua PTUN dengan acara singkat, penulis melakukan penelitian mengenai hal tersebut di Pengadilan Tata Usaha Negara Denpasar yang ditinjau berdasarkan posisi kasus dengan melakukan komparasi atau perbandingan antara perkara dengan Nomor 10/PLW/2018/PTUN.DPS dan Perkara Nomor 15/PLW/ 2018/PTUN.DPS.

Berdasarkan paparan di atas, dirumuskan beberapa permasalahan yang kemudian dikaji dalam penelitian ini, yakni seperti di bawah ini:

1. Bagaimana mekanisme penyelesaian upaya perlawanan sebagai akibat pernyataan dismissal oleh Ketua Pengadilan Tata Usaha Negara?

2. Apa yang menjadi dasar pertimbangan Majelis Hakim dalam memutus upaya perlawanan sebagai akibat pernyataan dismissal oleh Ketua PTUN Denpasar?

Tujuan penelitian ini adalah:

1. Untuk dapat mengetahui mengenai apa yang dimaksudkan dengan proses penyaringan di PTUN dan penyelesaian upaya perlawanan.

2. Untuk menyoroti bahan pemahaman tentang dasar pertimbangan Hakim dalam pemutusan upaya perlawanan sebagai akibat pernyataan dismissal dan dasar-dasar pertimbangan hukum dalam studi kasus Nomor Perkara: 10/PLW/2018/PTUN.DPS dan 15/PLW/2018/PTUN.DPS.

\section{METODE PENELITIAN}

Mengingat penelitian ini merupakan proses menemukan aturan hukum, prinsip hukum, maupun pendapat hukum yang nantinya berguna untuk menjawab isu hukum yang dihadapi, penelitian ini bersifat deskriptif analitis yang berusaha untuk memberi gambaran secara rinci mengenai kasus yang diteliti (Marzuki, 2005). Oleh karena itu tipe penelitian ini adalah yuridis normatif dengan pendekatan Undang-undang (statute approach) dan pendekatan kasus (case approach). Kedua pendekatan ini diterapkan karena sifat penelitian deskriptif analitis dalam penelitian ini dapat digambarkan secara rinci dan seimbang yankni antara teori dan aplikasi yang dilakukan di Pengadilan Tata Usaha Negara.

Penelitian hukum ini tergolong penelitian hukum normatif. Data yang diperlukan meliputi:

1. Baham hukum primer, yaitu undang-undang dan putusan pengadilan yang sudah memiliki kekuatan hukum tetap. Bahan-bahan hukum yang dikumpulkan dalam penelitian ini, antara lain ialah Undang-undang PTUN Nomor 5 Tahun 1986 yang telah dirubah sebanyak 2 kali, Surat Edaran Mahkamah Agung (SEMA) Nomor 2 Tahun 1991 tentang Petunjuk Pelaksana Beberapa Ketentuan Dalam Undang-Undang Nomor 5 Tahun 1986, Surat Mahkamah Agung No. 224/Td.TUN/X/19993 Tanggal 14 Oktober 1993 tentang Petunjuk Pelaksanaan yang dirumuskan dalam Pelatihan Hakim Pengadilan Tata Usaha Negara Tahap III Angka VII, dan Putusan PTUN Jakarta Nomor 02/PLW/1993-PEN/PTUN-JKT 
2. Bahan hukum sekunder yaitu bahan untuk mendukung bahan hukum primer. Penelitian ini juga menggunakan bahan hukum yang berupa buku-buku yang berkaitan dengan judul penelitian skripsi seperti hasil penelitian berupa buku-buku dan hasil-hasil penelitian relevan.

Pengumpulan bahan hukum dilakukan dengan menggunakan metode inventarisasi bahan hukum yang berkaitan dengan objek kajian penelitian ini, dimana bahan hukum primer dan sekunder dikumpulkan dari perpustakaan, dan kemudian dilakukan Identifikasi dan Klasifikasi agar mempermudah mencari bahan-bahan hukum.

\section{HASIL DAN PEMBAHASAN \\ Mekanisme Penyelesaian Upaya Perlawanan sebagai Akibat Pernyataan Dismissal oleh Ketua Pengadilan Tata Usaha Negara}

Penyelesaian atas kasus tindakan perlawanan tidak dapat menggunakan kembali upaya hukum. Adapun susbtansi dari perlawanan tersebut pada esensinya ialah bahwa gugatan penggugat telah sempurna atau telah benar-benar sesuai dengan fakta yang termuat dalam gugatan, dan tidak memenuhi pengecualian yang termuat dalam Pasal 62 Ayat (1) Huruf A sampai dengan Huruf E Undang-Undang PTUN.

Bentuk upaya perlawanan tersebut bertujuan memberikan kesempatan kepada Pelawan untuk melakukan pengujian ulang terhadap obyek sengketa, mengingat dalam Penetapan Ketua PTUN perkara tersebut hanya diputus berdasarkan data-data awal (pra bukti) dan hanya dilakukan oleh seorang hakim (Ketua PTUN) sedangkan persidangan perlawanan dilakukan oleh Majelis Hakim yang terdiri dari 3 (tiga) orang hakim yang mana pemikiran dengan hasil putusan antara 3 (tiga) orang dengan satu orang tentu berbeda. Selain itu dalam persidangan perlawanan pertimbangannya bukan hanya berupa pra bukti tetapi juga bukti-bukti otentik baik berupa akta tertulis maupun keterangan saksi-saksi dipersidangan

UU tidak mempunyai batasan mengenai tata cara pemeriksaan terhadap perlawanan sebagai akibat penetapan dismissal yang hanya disebutkan di dalamya bahwa upaya perlawanan ini diselesaikan dengan acara singkat (Wiryono, 2016); dan oleh sebab itu Mahkamah Agung Republik Indonesia mengeluarkan surat melalui Ketua Muda Mahkamah Agung Urusan Lingkungan Peradilan Tata Usaha Negara dengan No. 222/Td/TUN/X/1993 dan 224/Td.TUN/X/19993 tertanggal 14 Oktober 1993 perihal Petunjuk Pelaksanaan yang dirumuskan dalam Pelatihan Hakim Pengadilan Tata Usaha Negara Tahap III Angka VII, yang dapat disimpulkan sebagai berikut:

1) Yang memeriksa gugatan perlawanan adalah Majelis Hakim;

2) Terhadap gugatan perlawanan oleh Hakim dilakukan tanpa pemeriksaan persiapan;

3) Gugatan perlawanan diperiksa secara tertutup, namun putusannya harus diucapkan dalam sidang yang disaksikan dan terbuka untuk umum;

4) Dalam memeriksa gugatan perlawanan kedua belah pihak didengarkan secara seimbang;

5) Terhadap putusan gugatan perlawanan tidak tersedia upaya hukum apapun, baik upaya hukum biasa maupun luar biasa; dan

6) Apabila pelawan mengajukan permohonan untuk banding ataupun upaya hukum lainnya, maka panitera berkewajiban membuat akta penolakan banding.

Setelah pemeriksaan dilakukan, apabila upaya yang diajukan oleh pihak pelawan dinyatakan tidak dibenarkan oleh Majelis Hakim maka dengan adanya putusan tersebut penetapan dismissal yang dikeluarkan mempunyai kekuatan hukum tetap, karena tidak dapat mengajukan upaya hukum biasa maupun luar biasa sesuai dengan yang termuat pada Pasal 62 Ayat (6).

Untuk mengetahui secara lebih rinci mengenai pengaplikasian hal ini, maka penulis meneliti 2 (dua) kasus yang diajukan di PTUN Denpasar dengan membandingkan agar mengetahui mekanisme penyelesaian, dasar pertimbangan terhadap kedua kasus dengan Nomor Perkara: 10/PLW/2018/PTUN.DPS dan 15/PLW/2018/PTUN.DPS. Kedua kasus yang dikaji ini tentu memiliki dasar pertimbangan yang berbeda-beda sebab menitikberatkan pada objek dari sengketa tersebut, yang nantinya akibat proses penyaringan penolak terhadap 2 perkara ini, yang kemudian diajukan melalui upaya perlawanan akan diperiksa oleh Majelis Hakim, untuk lebih dapat memberikan gambaran dan pemahaman yang lebih jelas mengenai mekanisme penyelesaian upaya perlawanan ini. 
Pertimbangan Majelis Hakim dalam Penyelesaian Upaya Perlawanan pada Perkara No 10/PLW/2018/PTUN.DPS dan 15/PLW/2018/PTUN.DPS

Pada dasarnya penyelesaian sengketa di PTUN bertujuan untuk mendorong terwujudnya pemerintah yang bersih dan berwibawa. Hal tersebut belum dapat dilaksanakan secara optimal disebabkan beberapa hal seperti berikut:

1) Kurangnya self respect dari Badan atau Pejabat Tata Usaha Negara untuk senantiasa mematuhi putusan Peradilan TUN sebagai sebuah batasan pelaksanaan kebijakan yang harus dipatuhi secara utuh.

2) Terjadinya kesenjangan atau ketidaksamaan antara Putusan PTUN yang menggunakan dasar pertimbangan keabsahan Keputusan PTUN berdasarkan hukum dengan pertimbangan kebijakan pemerintah yang didasarkan pada perubahan peraturan perundang-undangan yang berlaku yang mengakibatkan tidak seimbang sehingga singkronisasi kedua hal ini tidak berjalan sebagaimana mestinya.

3) Tidak digunakannya prinsip Utra Petita dalam putusan PTUN.

Terkait dengan perkara ini, penulis menilai pengajuan upaya perlawanan merupakan sebuah bukti konkrit bahwa masih banyak yang belum memahami jenis perkara yang menjadi kompetensi dari Pengadilan TUN, khususnya yang diajukan di Denpasar. Kedua perkara yang diajukan ini dinyatakan tidak lolos dismissal oleh ketua PTUN, yang kemudian kedua perkara ini kembali diajukan dengan upaya perlawanan. Di dalam pengajuannya, penulis mengkaji dua kasus upaya perlawanan ini, sebab terdapat suatu hal yang perlu dijadikan sebagai acuan dalam pengajuan sengketa ke PTUN.

Dalam konteks kasus yang dikaji dalam penelitian ini, upaya perlawanan dengan Nomor Perkara 10/PLW/2018/PTUN.DPS yang diajukan oleh pelawan atas nama Hari Boedi Hartono berawal dari mengajukan gugatan ke Pengadilan Tata Usaha Negara Denpasar pada Tanggal 27 April 2018 dengan No. Perkara 10/G/2018/PTUN.DPS melawan Kepala Kantor Pertanahan Kabupaten Badung tetapi kemudian Ketua PTUN Denpasar menolak perkara tersebut dengan pertimbangan yang dituangkan dalam penetapan dismissal dengan Nomor Perkara: 10/PEN.DIS/2018/PTUN.DPS Tanggal 23 Mei 2018, yang menyatakan bahwa terhadap objek sengketa berupa Surat Keputusan Kantor Pertanahan Kabupaten Badung No 2937/Pbt/BPN.51/IX/2017 Tanggal 20 September 2017, tentang Pembatalan Sertifikat Hak Milik No. 3023/Kelurahan Jimbaran. Gambar situasi No. 2454/1995 Tanggal 24 Juni 1995, lokasi objek sengketa ialah seluas $10.800 \mathrm{~m}^{2}$ yang terletak di Kelurahan Jimbaran, Kecamatan Kuta Selatan, Kabupaten Badung, Provinsi Bali. Tercatat tanah tersebut dalam sertifikat ialah atas nama Hari Boedi Hartono. Dalam faktanya itu diterbitkan berdasarkan putusan pengadilan yang ialah Putusan Pengadilan Negeri Denpasar Nomor: 146/pdt.G/2010/PN.DPS Tanggal 1 September 2010, Putusan Pengadilan Tinggi Bali Nomor: 20/PDT/2011/PT.DPS Tanggal 29 April 2011, Putusan MA RI Nomor 65 k/pdt/2013 Tanggal 31 Mei 2012 dan Putusan Peninjauan Kembali Nomor 626/ PK/Pdt/2013 Tanggal 28 November 2014 (sudah berkekuatan hukum tetap). Oleh karena itu berdasarkan fakta hukum tersebut Majelis Hakim menyatakan alasan serta dasar pertimbangan hukum, yakni dalam perkara tersebut yang menjadi obyek sengketa termasuk dalam pengertian Keputusan Tata Usaha Negara yang dikecualikan, sesuai dengan yang diatur dalam ketentuan Pasal 2 Huruf e Undang-Undang Nomor 9 Tahun 2004 tentang Perubahan atas Undang-Undang Nomor 5 Tahun 1986 tentang PTUN, sehingga pernyataan dismissal oleh Ketua PTUN sudah tepat. Dengan demikian PTUN tidak berwenang untuk memeriksa, memutus, dan menyelesaikan dan Majelis Hakim menyatakan bahwa gugatan perlawanan yang diajukan pelawan tidak dapat diterima.

Perkara tersebut berbeda dengan perkara Nomor 15/PLW/2018/PTUN.DPS, yang mana, dalam perkara ini yang menjadi objek adalah Surat Keputusan No. 02/BWI/BALI/NZ/2015 Tanggal 9 Desember 2015 tentang Pergantian Nazhir Tanah Wakaf Masjid Al Hikmah Denpasar yang diterbitkan oleh Perwakilan Badan Wakaf Indonesia (BWI) Propinsi Bali. Perkara ini diajukan oleh H. M. Suwarno., SH. Dkk., yang selanjutnya disebut para penggugat yang terdaftar pada Tanggal 20 Juli 2018 di Kepaniteraan Pengadilan TUN dengan Nomor Perkara: 15/G/2018/PTUN.DPS yang merasa kepentingannya dirugikan akibat terbitnya objek sengketa, yang tidak mencantumkan kelima penggugat dalam pembaharuan Nazhir pada Yayasan Al Hikmah periode 2014-2019.

Terhadap perkara tersebut Ketua PTUN dengan pertimbanganya menolak gugatan tersebut dengan mengeluarkan Penetapan Dismissal Ketua PTUN Nomor: 15/PEN. DIS/2018/PTUN.DPS pada tanggal 28 Agustus 2018, yang dengan pertimbangannya untuk penyelesaian sengketa wakaf terkait pergantian Nadzir sesuai dengan Undang-Undang Nomor 41 Tahun 2004 tentang Wakaf merupakan kewenangan 
Pengadilan Agama atau Mahkamah Syariah untuk menyelesaikannya, yang kemudian atas penetapan dismissal tersebut diajukan upaya hukum perlawanan.

Dalam pemeriksaan ini Majelis Hakim telah memutuskan bahwa dalam perkara yang menyangkut tentang perwakafan telah terdapat pembatasan kompetensi absolut PTUN dengan adanya peraturan Perundang-undangan lain yang mengatur mengenai wakaf tersebut yaitu Undang-Undang No. 41 Tahun 2004. Majelis Hakim membenarkan pertimbangan hukum Ketua PTUN yang menyatakan gugatan yang diajukan pelawan telah memenuhi ketentuan Pasal 62 Ayat (1) Huruf a Undang-Undang No. 5 Tahun 1986 tentang PTUN yang terkait dengan wakaf ini merupakan kewenangan Pengadilan Agama atau Mahkamah Syari'ah untuk memeriksa, memutus, dan menyelesaikan mengenai gugatan tersebut. Maksud dari penyelesaian ini dapat diselesaikan melalui musyawarah untuk mufakat. Jika masih belum menemukan titik temu, terdapat opsi atau pilihan lain seperti mediasi, abitrase atau pengadilan. Yang dimaksud dengan mediasi dalam hal ini adalah dengan menerima bantuan dari pihak ketiga yang bersengketa, namun apabila hal tersebut juga tidak berhasil maka sengketa tersebut dapat dibawa kepada badan abitrase syar'iah. Apabila tidak dapat ditemukan titik terang maka sengketa ini dapat diajukan ke Pengadilan Agama atau Mahkamah Syariah.

\section{SIMPULAN DAN SARAN \\ Simpulan}

Berikut ialah beberapa simpulan atas penelitian ini menurut hasil yang telah dipaparkan dan pembahasan yang telah diberikan.

1. Undang-Undang PTUN digunakan sebagai acuan dalam menyatakan gugatan dapat diproses atau tidak melalui tahap penyaringan, yang kemudian akan diperiksa dan diputus oleh Hakim yang sesuai ditunjuk oleh Ketua Pengadilan dengan acara singkat. Apabila perlawanan pengugat diterima, penetapan tidak lolos dismissal ketua pengadilan dibatalkan. Selanjutnya pokok gugatan akan diperiksa dan diputus menurut acara biasa; sebaliknya, apabila verzet ditolak oleh Majelis Hakim yang memeriksa, maka tidak ada lagi upaya hukum yang dapat ditempuh oleh penggugat. Terhadap putusan perlawanan atas penetapan dismissal oleh Ketua Pengadilan TUN tidak tersedia upaya hukum apapun juga. Mekanisme upaya perlawanan ini diawali dengan dengan pengajuan gugatan tidak lebih dari tenggang waktu 14 hari sejak dikeluarkannya penetapan oleh Ketua PTUN setelah diterima dan terdaftar di buku register, yang kemudian akan ditunjuk Majelis Hakim yang memeriksanya, yang pemeriksaannya hanya mengenai dasar pertimbangan Ketua PTUN mengenai tepat tidaknya penetapan penolakan tersebut.

2. Atas proses pemeriksaan gugatan yang diajukan di PTUN yang telah ditetapkan bahwa tidak lolos proses dismissal oleh KTUN dengan Perkara Nomor: 10/PLW/2018/PTUN.DPS dan 15/PLW/2018/PTUN.DPS dalam hal pokok pertimbangannya Majelis Hakim dalam memutus perlawanan ini, mempertimbangkan alasan serta dasar pertimbangan hukum Ketua PTUN Denpasar dan yang terdapat di dalam penetapannya bahwa keputusan objek sengketa adalah termasuk dalam kategori keputusan yang dikecualikan sebagai Keputusan Tata Usaha Negara.

\section{Saran}

Ada dua macam rekomendasi yang diberikan menurut hasil penelitian ini, yakni seperti yang diuraikan berikut.

1. Perlu meninjau ulang ketentuan yang diatur dalam Pasal 62 Ayat (6) UU PTUN, sebab dalam sidang perlawanan, Hakim tidak sampai memeriksa pokok perkaranya. Oleh karena itu dalam satu sisi ada celah bagi pihak penggugat yang mengajukan perlawanan karena harapan keadilan dibatasi oleh ketentuan dalam Undang-undang tentang tidak adanya upaya hukum perlawanan.

2. Sebaiknya ada regulasi atau pengaturan lebih lanjut dalam perma ataupun sema mengenai petunjuk persidangan dengan acara singkat, juga dalam SIPP (Sistem Informasi Penelusuran Perkara) yang juga perlu segera diperbaharui dengan menambahkan kolom penetapan jadwal persidangan (court calendar) karena belum ada template mengenai penetapan jadwal persidangan (court calendar) sedangkan hal tersebut menunjang dalam kelancaran pemeriksaan perkara agar tepat waktu.

\section{DAFTAR PUSTAKA}

Elijana, \& Dkk. (2015). Naskah Akademik Rancangan Undang-undang tentang Hukum Acara Perdata. Kepala Badan Pembinaan Hukum Nasional. 
Hasanah, S. (2016). Perbedaan Acara Biasa, Acara Cepat, dan Acara Singkat Pada Peradilan TUN. Hukum Online.Com.

Marzuki, P. M. (2005). Penelitian Hukum. Kencana.

Pattipawae, D. R. (2015). Fungsi Pemeriksaan Dismissal dalam Peradilan Tata Usaha Negara. Jurnal Sasi, 20(1), 37-54.

Pradana, I. P. R., \& Marwanto. (2013). Pelaksanaan Rapat Permusyawaratan Dalam Peradilan Tata Usaha Negara. Kerthanegara, 1(1), 1-5.

Soetami, S. (2005). Hukum Acara Peradilan Tata Usaha Negara. Refika Aditama.

Wiryono, R. (2016). Hukum Acara Peradilan Tata Usaha Negara (Tarmizi \& Ihsan (eds.)). Sinar Grafika.

Zurahmah, \& Umar, F. (2014). Pelaksanaan Tata Cara Penolakan (Dismissal Procedure) dalam Penyelesaian Perkara Pertanahan (Studi Kasus di Pengadilan Tata Usaha Negara Makassar). Tomalebbi, 1(2), 108-123. 